\title{
COMPARATIVE TRANSPIRATION STUDIES ON THE INVASIVE EASTERN REDCEDAR (JUNIPERUS VIRGINIANA L.) AND ADJACENT WOODY TREES
}

\author{
Adjoa Richardson Ahedor \\ Bethany Spitz \\ Michael Cowan \\ J'nae Miller \\ Margaret Kamara \\ Engineering and Science Division \\ Rose State College \\ Midwest City, OK 73110 \\ aahedor@rose.edu
}

Keywords: loblolly pine, bur oak, eastern cottonwood, white mulberry

\begin{abstract}
Fire suppression and grazing on the Great Plains have resulted in alteration of the grassland ecosystem, including an increase in woody trees. Eastern redcedar (Juniperus virginiana L.) is a native but invasive conifer that is rapidly expanding its range in Oklahoma due to human and ecological factors and the ability to tolerate aridity. It is known to reduce soil moisture due to high rates of water uptake compared to neighboring grasses and herbaceous species. The objectives of this study were to compare average amounts of water transpired between eastern redcedar and adjacent woody trees in central Oklahoma to determine how water loss in the conifer compares with other trees in the same locality. Average amounts of transpiration in eastern redcedar were compared with those of loblolly pine (Pinus taeda L.), white mulberry (Morus alba L.), eastern cottonwood (Populus deltoides W. Bartram ex Marshall) and bur oak (Quercus macrocarpa Michx.). Three to six branch tips per tree were securely bagged over 24-hour periods, and water collected in each bag was weighed and analyzed. Three to five sampling months spanning two or three seasons were conducted for each comparative study. Results indicated that for winter, spring, and fall, transpiration from eastern redcedar exceeded that from the other tree species. Weather variables such as day length and temperature were found to have strong to moderate effects on transpiration in eastern redcedar. Day length and temperature also had strong effects on transpiration in white mulberry and bur oak, respectively, and humidity had an effect on transpiration in loblolly pine. No reliable or significant effect of weather variables was detected in eastern cottonwood.

\section{INTRODUCTION}

Eastern redcedar (Juniperus virginiana L.) is the most widely distributed evergreen in the eastern half of the United States (Smith 2011; Van Haverbeke and Read 1976) and extends into the Great Plains (van Els et al. 2010). In 1950, eastern redcedar occurred

on about 1.5 million acres of Oklahoma (Bernardo 1986). By 1985, the conifer had expanded its range to 3.5 million acres, and by 1994, it had spread to almost 6 million acres of land in Oklahoma (Bernardo 1986; McKinley 2012). This indicates an increase of about $79 \%$ in less than 50 years. In 1985 , a survey by the Soil Conservation Service
\end{abstract}


indicated that eastern redcedar, though native, has become invasive and widespread (Snook 1985). In the last few decades, eastern redcedar is rapidly expanding its range in the southern Great Plains primarily due to fire suppression (Bragg and Hulbert 1976), livestock overgrazing (Van Auken 2009; Briggs et al. 2002), and rapid seed germination (Horncastle et al. 2004). It is a pioneer species in old fields and pastures protected from fires. Eastern redcedar is estimated to be currently expanding its range at a rate of 300,000 acres (121405.69 hectares) per annum in the Oklahoma rangelands and prairies (Hung 2012). Although native to the state, it is considered to be drought-tolerant, invasive (Snook 1985; Bihmidine et al. 2010), and well adapted to the semi-arid climate of the state partly due to the presence of scale-like leaves, a thick cuticle, sunken stomata, and fibrous roots typical of conifers.

The fast encroachment of eastern redcedar has raised concern among scientists, land owners, ranchers, water resource managers, and policy makers as a hindrance to water conservation (Hung 2012). The encroachment of eastern redcedar is expected to cause a decline in soil moisture, stream flow, and water supply due to its relatively high water uptake capability compared to native grasses in the same habitat (Huxman et al. 2005). It is estimated that one acre of eastern redcedar trees can absorb up to 55,000 gallons (ca. $208,000 \mathrm{~L}$ ) of water every year, thereby reducing soil water availability to grasses and other herbaceous species (Briggs et al. 2002).

Research on the effect of eastern redcedar in grassland ecosystems has focused primarily on water use efficiency, impact on soil moisture, and effect on adjacent native grass species (Hung 2012; Awada et al. 2013). However, as a droughttolerant invader in the semi-arid grassland of Oklahoma, it is important to investigate the amount of water transpired from eastern redcedar. Previous studies have shown that in loblolly pine (Pinus taeda L.), green ash (Fraxinus pennsylvanica Marshall), and sunflower (Helianthus annuus L.) high rates of transpiration during the day enhanced root absorption at night in the sense that the rate of water intake was largely determined by the rate of water loss (Kramer 1937). The current study was designed to determine the average amount of water transpired from branch tips with intact leaves of eastern redcedar and adjacent trees in four localities in central Oklahoma. The objectives of the study were to 1) compare the average amounts of transpiration in eastern redcedar and adjacent trees in the same habitat and 2) determine how climatic factors such as temperature, humidity, day length, and wind speed affect transpiration in the trees. Results will be useful in understanding the potential amount of water transpired from eastern redcedar. Because most broadleaf deciduous trees in the area are dormant in the winter season, the focus of the study was to assess the level of transpiration in eastern redcedar (and loblolly pine) during the cold seasons, the beginning and end of the warm seasons when deciduous trees are refoliating or defoliating.

\section{MATERIALS AND METHODS}

Sampling was conducted on trees growing in central Oklahoma at both urban and rural sites. Three deciduous tree species: white mulberry (Morus alba L.), eastern cottonwood (Populus deltoides W. Bartram ex Marshall), and bur oak (Quercus macrocarpa Michx.) and one evergreen conifer, loblolly pine, were selected for the comparative studies, in addition to eastern redcedar. These tree species were sampled because they were growing in the same locality on yards and ranches accessible to undergraduate researchers. A total of four sites were selected, three in Oklahoma County and one in Pottawatomie County. At each site, one to three eastern redcedar 
trees were sampled adjacent to one to three comparable trees. The Oklahoma County sites contained eastern redcedar and white mulberry in downtown Oklahoma City $\left(35.4754^{\circ} \mathrm{N}, 97.5330^{\circ} \mathrm{W}\right)$, eastern redcedar and eastern cottonwood in urban southeastern Oklahoma City $\left(35.4111^{\circ} \mathrm{N}\right.$, $\left.97.5556^{\circ} \mathrm{W}\right)$, and eastern redcedar and loblolly pine in rural, wooded southeastern Oklahoma City $\left(35.4249^{\circ} \mathrm{N}, 97.3260^{\circ} \mathrm{W}\right)$. Eastern redcedar and bur oak were studied at a site in rural northwestern Pottawatomie County $\left(35.4359^{\circ} \mathrm{N}, 97.0917^{\circ} \mathrm{W}\right)$. The investigations were conducted in two parts, a fall study (September-December) of eastern redcedar and bur oak and a spring study (February-June) of eastern redcedar and loblolly pine, eastern cottonwood and white mulberry.

To assess transpiration, clear plastic bags $68.5 \mathrm{~cm} \times 60.9 \mathrm{~cm}$ (HDX Waste Basket Liners) were used to enclose branch tips (Robinson and Donaldson 1967). Each bag was examined for holes or open seams prior to use. The mass of each empty bag was estimated ( $\left.\mathrm{W}_{\mathrm{i}} ; \mathrm{g}\right)$, and it was tightly secured with twine around three to six branch tips on each tree (Jadrich and Bruxvoort 2011). Branch tips ranged in length from $60-65 \mathrm{~cm}$. Branch tips had approximately 30-40 leaves and needles, except for eastern redcedar that had numerous scales that could not be counted. Leaf surface area was not measured since leaves remained intact on branches, and many were high up on the branches and individual leaves could not be easily measured. Bags securely fastened on branches were left overnight for a 24-hour period, after which they were carefully removed and mass was measured $\left(\mathrm{W}_{\mathrm{f}} ; \mathrm{g}\right)$. The mass of water $\left(\mathrm{W}_{\mathrm{w}} ; \mathrm{g}\right)$ collected in each bag was determined by subtracting $\mathrm{W}_{\mathrm{i}}$ from $\mathrm{W}_{\mathrm{f}}$, that is, $\mathrm{W}_{\mathrm{w}}=\mathrm{W}_{\mathrm{f}}-\mathrm{W}_{\mathrm{i}}$. Branch tips sampled per tree were varied weekly to achieve greater sampling of each tree. Branch tips high up on a tree were reached by carefully climbing ladders. The same side(s) of adjacent trees were bagged each time for consistency and to minimize microclimate effect. To assess the potential of condensation inside bags, additional bags were closed and left outside for each sampling event. Condensation was either negligible or completely absent after $24 \mathrm{~h}$, particularly after the early morning hours when bags were examined. Because sampling for each tree species at each site was conducted at the same time, the influence of condensation on the results was uniform across species. Experiments were suspended during rainy or windy days to avoid accidental influx of rain water in the bags or puncturing/removal of bags due to excessive wind. The experiment was conducted weekly over three to five months. The local weather (temperature, humidity, wind speed, precipitation, and day length) was recorded for each sampling day by accessing Oklahoma Mesonet Weather reports (Oklahoma Climatological Survey 2017). Following rainfall events, precipitation levels were recorded, but due to persistent rainfall in the spring, there were entire weeks when sampling was suspended. The bagging technique is typically used in classroom demonstrations (Jadrich and Bruxvoort 2011) but has potential for research applications explored here. However, if bags were not firmly secured, they could have been blown away by the wind or punctured. Furthermore, changes in ambient temperature could cause condensation of moisture in the air originally trapped in the bag during bagging. Temperatures were typically mild or low, except for a few sampling days when temperatures were high; thus, condensation in bags due to ambient high temperature was either absent or negligible.

The total amount of water collected (transpired) was organized into tables for each investigation and analyzed using PASW Statistics ver. 18.0 for Windows Predictive Analysis SoftWare (SPSS, Inc. 2009). Normality tests were conducted to

Adjoa R. Ahedor, et al. 
determine the appropriate analysis (parametric or non-parametric) for each dataset. Due to the small sample size in each investigation $(<50)$, Shapiro-Wilk test was conducted instead of K-S test. Ghasemi and Zahediasi (2012) reported that Shapiro-Wilk test is more reliable in testing data with a small sample size of fewer than 50 . The eastern redcedar and loblolly pine data were analyzed using a t-test of the hypothesis that these species experience equal transpiration rates after conducting Levene's test for equality of variances. The remaining comparison involved significantly nonnormal data, and differences were tested using Mann Whitney U tests (SPSS Inc. 2009; Zar 1996). The significance level (alpha) was set at 0.05 for all statistical analyses. Correlations between weather variables and transpiration for each comparison investigation were determined by conducting paired samples t-tests using SPSS (SPSS, Inc. 2009).

\section{RESULTS}

\section{Tests for Normality}

Results of the normality tests (ShapiroWilk tests) indicated that for the spring study most of the data were normal (as significance levels were higher than 0.05) except for white mulberry, and eastern redcedar compared with eastern cottonwood (Table 1). The Shapiro-Wilk test also indicated that for the fall study data obtained for eastern redcedar were not normal ( $\mathrm{p}$-value $=0.017)$ and bur oak data were normal $(\mathrm{p}$-value $=0.097)($ see Table 1$)$. Transpiration rates for eastern redcedar growing with loblolly pine were normal.

Table 1 Results of Shapiro-Wilk Normality Tests for data obtained for all comparison studies. Significance level $(\mathrm{P}$-value $)=0.05$. P-values greater than 0.05 indicate normal data; less than 0.05 indicate not normal data.

\begin{tabular}{lccc}
\hline & Statistic & $\begin{array}{c}\text { Degrees of } \\
\text { freedom (df) }\end{array}$ & $\begin{array}{c}\text { Significance } \\
\text { Level (p-value) }\end{array}$ \\
\hline Spring & 0.935 & 13 & 0.401 \\
Eastern redcedar & 0.814 & 13 & 0.010 \\
White mulberry & 0.897 & 9 & 0.237 \\
Eastern redcedar & 0.857 & 9 & 0.090 \\
Loblolly pine & & & 0.0001 \\
& 0.750 & 15 & 0.495 \\
Eastern redcedar & 0.948 & 15 & \\
Eastern cottonwood & & & 0.017 \\
Fall & & 15 & 0.097 \\
Eastern redcedar & 0.850 & 15 & \\
Bur oak & 0.900 & & \\
\hline
\end{tabular}




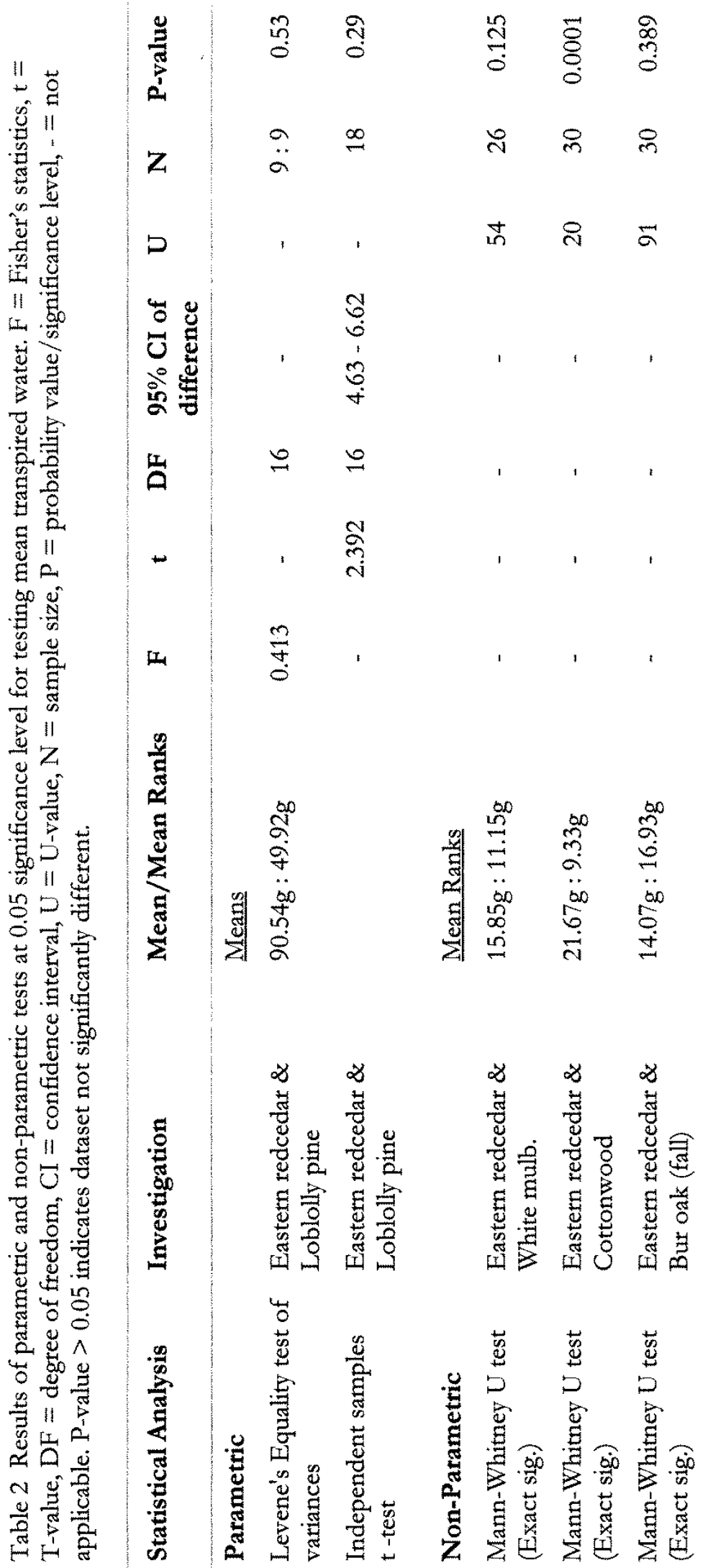



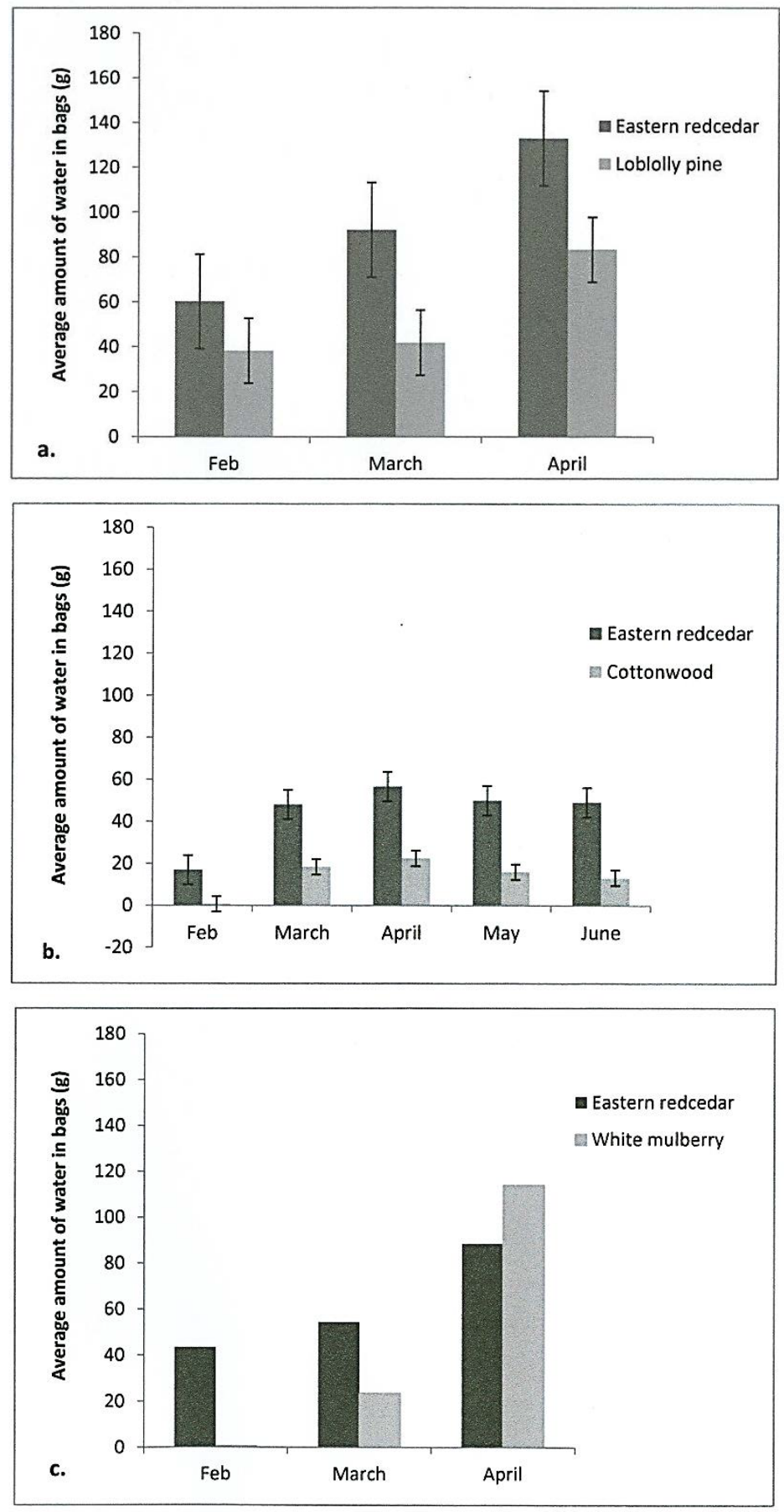

Figure 1 Average monthly transpiration measured in the spring study for (a) comparison study between eastern redcedar and loblolly pine conducted in rural southeastern Oklahoma City, (b) comparison study between eastern redcedar and eastern cottonwood conducted in urban southeastern Oklahoma City, and (c) comparison study between eastern redcedar and white mulberry conducted in downtown Oklahoma City. Bars represent means of water collected for all trees during the sampling period. Standard error bars represent distribution of overall data obtained for three trees per species ( $\mathrm{a}$ b). Bars without error bars represent means of water collected for one tree per species (c). All sites were located in Oklahoma County. 


\section{Spring Study: eastern redcedar and loblolly pine, white mulberry and eastern cottonwood}

The variances of eastern redcedar and loblolly pine did not differ significantly (Levene's test: $\mathrm{F}=0.413, \mathrm{p}=0.53$, df $=$ 16). The mean amount of water transpired did not differ between these species ( $\mathrm{t}$-test: $\mathrm{t}$ $=2.392, \mathrm{p}=0.29, \mathrm{df}=16)($ Table 2). The mean amount of water transpired by eastern redcedar was $90.54 \mathrm{~g}$; whereas, the mean for loblolly pine was $49.92 \mathrm{~g}$. Results of MannWhitney tests indicated that the difference in mean transpiration was not significant between eastern redcedar and white mulberry $(\mathrm{U}=54, \mathrm{~N}=26, \mathrm{p}=0.125)$ but was significant between eastern redcedar and eastern cottonwood $(\mathrm{U}=20, \mathrm{~N}=30, \mathrm{p}$ $=0.0001$ ) (see Table 2). Average monthly transpiration increased steadily in all trees from winter to spring (Figure 1a - c).
Eastern redcedar transpired on all sampling days at all three sites, and its average transpiration was also higher than that by eastern cottonwood in each month from February to June (see Figure 1b). In the comparisons of total transpired water between eastern redcedar and either loblolly pine or eastern cottonwood, $64 \%$ and $70 \%$ respectively of the total amounts of water transpired were obtained from eastern redcedar (Table 3). In the spring, significant effect was detected between day length and transpiration in eastern redcedar (Figure 2), and white mulberry (Table 4). Humidity also had some effect on transpiration in loblolly pine, but no effect was detected in the remaining tree species, including eastern redcedar (see Table 4). Results on precipitation were inconclusive due to very small sample size.

Table 3. Total amounts of water transpired over entire sampling periods and overall percentages of total water mass sampled from eastern redcedar alone. $\mathrm{N}=$ number of sampling days.

$\begin{array}{lll}\text { Comparison } & \mathbf{W}_{\mathrm{w}}-\text { Total mass } & \begin{array}{l}\text { Percent of total } \\ \text { of water in bags } \\ \text { water transpired } \\ \text { from Eastern } \\ \text { redcedar }(\%)\end{array}\end{array}$

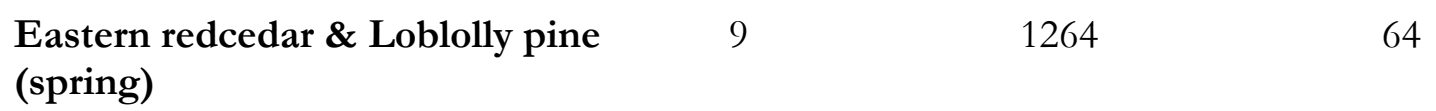

$\begin{array}{llll}\text { Eastern redcedar \& Eastern } & 15 & 1086 & 70 \\ \text { cottonwood (spring) } & & & \end{array}$

$\begin{array}{llll}\text { Eastern redcedar } \boldsymbol{\&} \text { White mulberry } & 13 & 981 & 50\end{array}$ (spring)

$\begin{array}{llll}\text { Eastern redcedar \& Bur Oak (fall) } & 15 & 1920 & 68\end{array}$ 


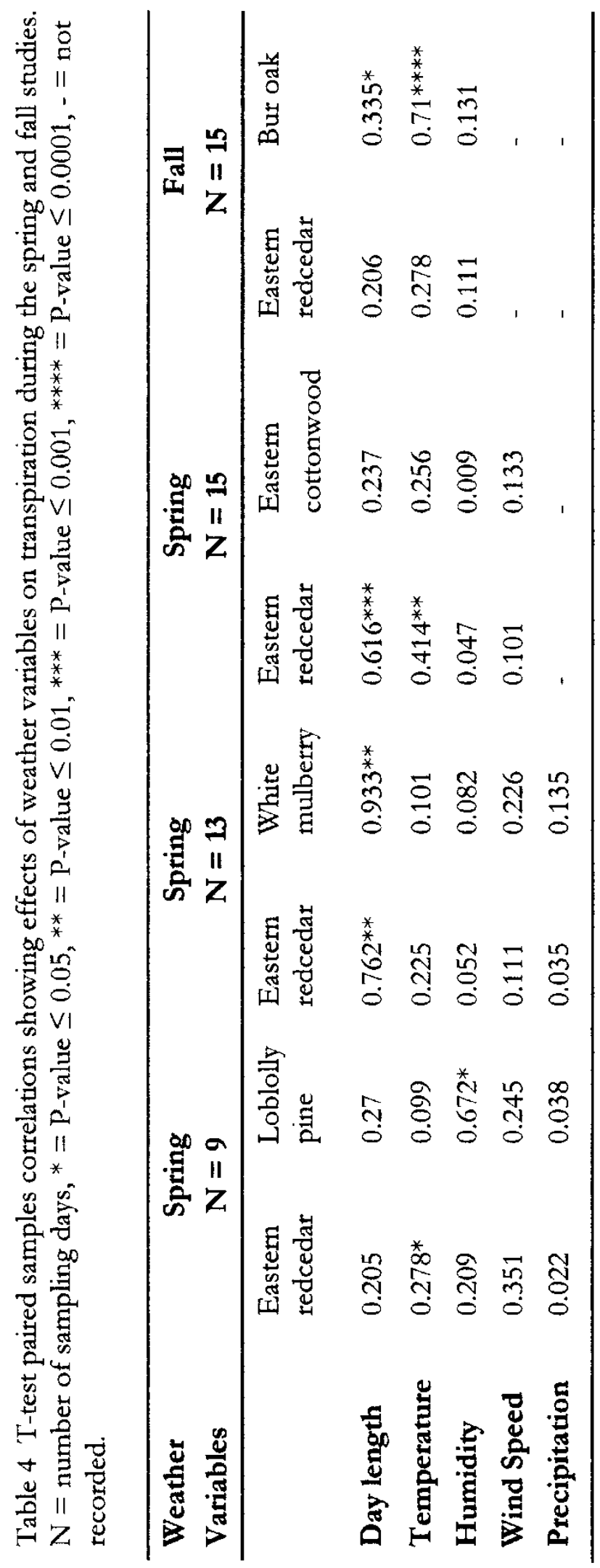

Adjoa R. Ahedor, et al. 


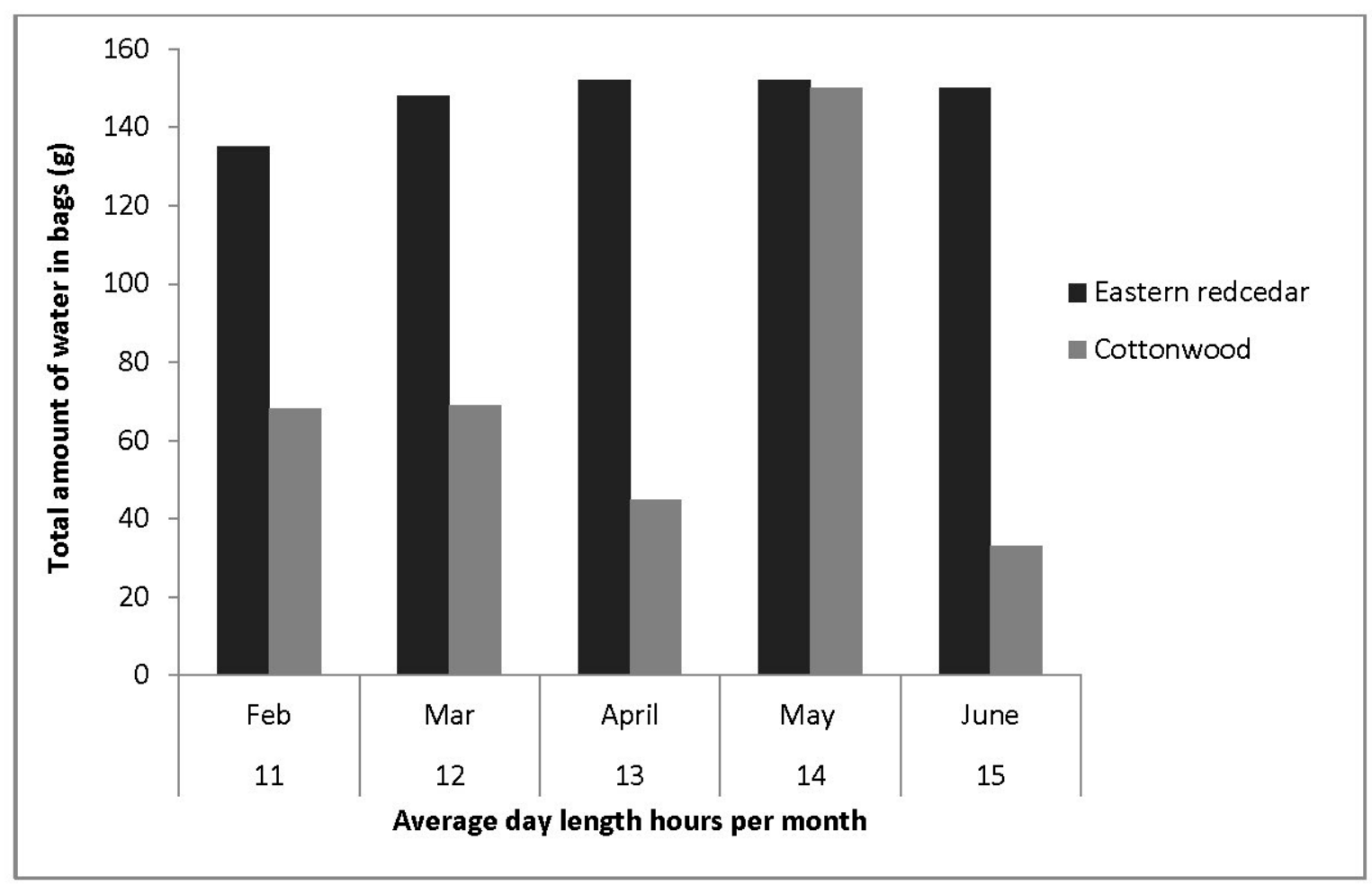

Figure 2 Effect of increasing day length on transpiration as observed in comparison study between eastern redcedar and eastern cottonwood in urban southeastern Oklahoma City

\section{Fall study: eastern redcedar and bur oak}

Results of Mann-Whitney U tests indicated that the ranks of median transpired water were not significantly different between eastern redcedar and bur oak $(\mathrm{U}=91, \mathrm{~N}=30, \mathrm{p}=0.389$ ) (see Table 2). However, similar to the spring study, eastern redcedar transpired throughout the entire sampling period (Figure 3) and 68\% of the total amount of water sampled in the entire study came from eastern redcedar (see Table 3). In eastern redcedar, transpiration was very low at high temperatures $\geq 90^{\circ} \mathrm{F}\left(32^{\circ} \mathrm{C}\right)$ but moderate at warm temperatures ranging from $77-88^{\circ} \mathrm{F}$ $\left(25-31^{\circ} \mathrm{C}\right)$ (Figure 4). In the winter when the temperature fell below freezing at $29^{\circ} \mathrm{F}$ ($\left.1.7^{\circ} \mathrm{C}\right)$, transpiration decreased in eastern redcedar to similar levels observed in the summer when temperatures were at $90^{\circ} \mathrm{F}$ and $94^{\circ} \mathrm{F}\left(34^{\circ} \mathrm{C}\right)$, respectively. In the late summer at high temperatures, transpiration in bur oak was very high, but as temperature decreased in the fall, transpiration decreased quickly as trees defoliated until transpiration completely stopped when temperatures reached below $44^{\circ} \mathrm{F}\left(7^{\circ} \mathrm{C}\right)$ and trees became dormant. Thus, temperature had a significant effect on bur oak but not on eastern redcedar (see Table 4). Day length was also found to have an effect on transpiration in bur oak but not eastern redcedar (see Table 4). As day length decreased from summer through fall, transpiration decreased in both bur oak and in eastern redcedar (see Figure 4 and Table 4). Effect of humidity and precipitation were not tested. 


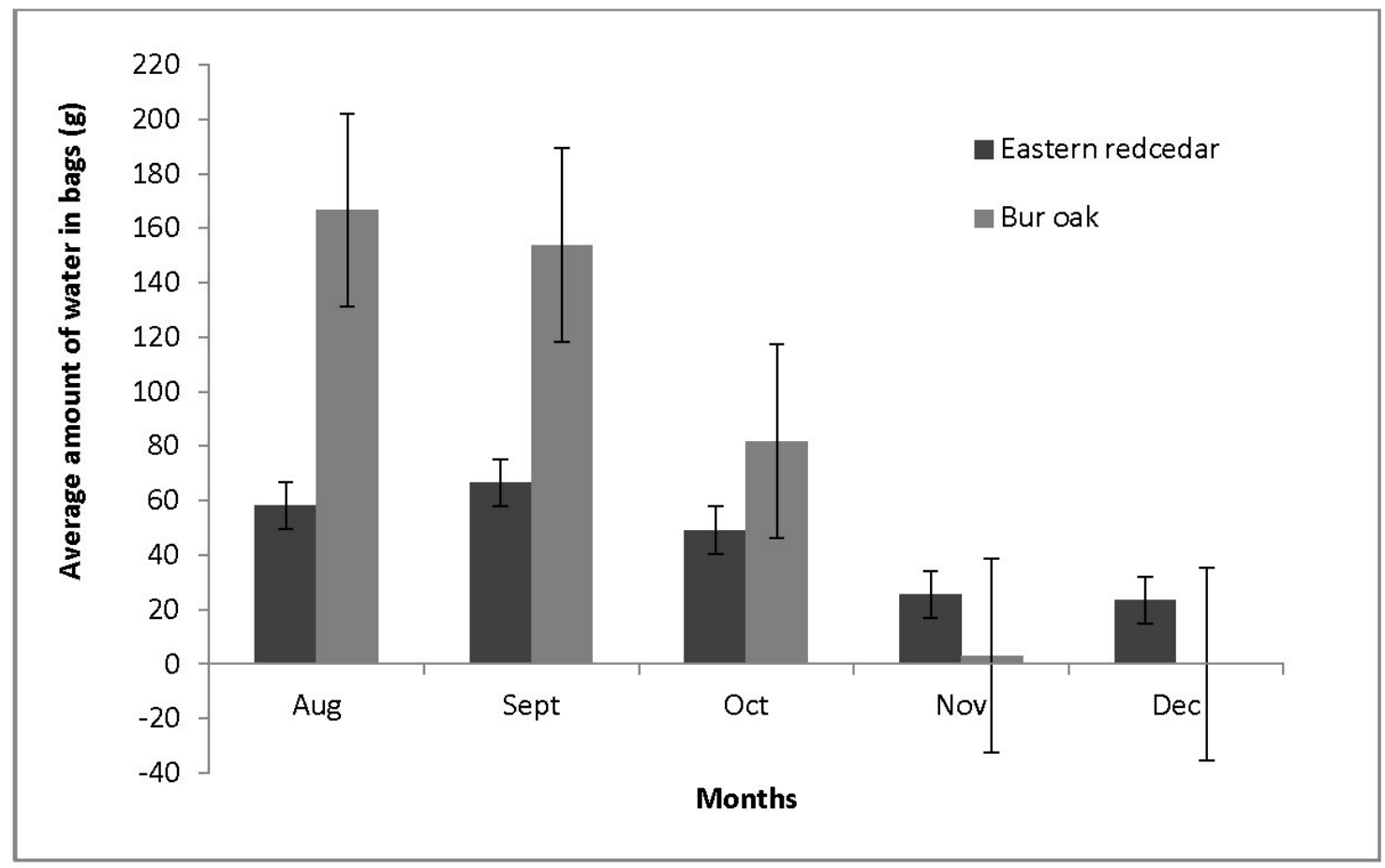

Figure 3 Average monthly transpiration measured for eastern redcedar and bur oak in the fall study in rural northwestern Pottawatomie County. Bars represent means of water collected for all trees that month. Standard error bars represent distribution of overall data obtained for three trees per species.

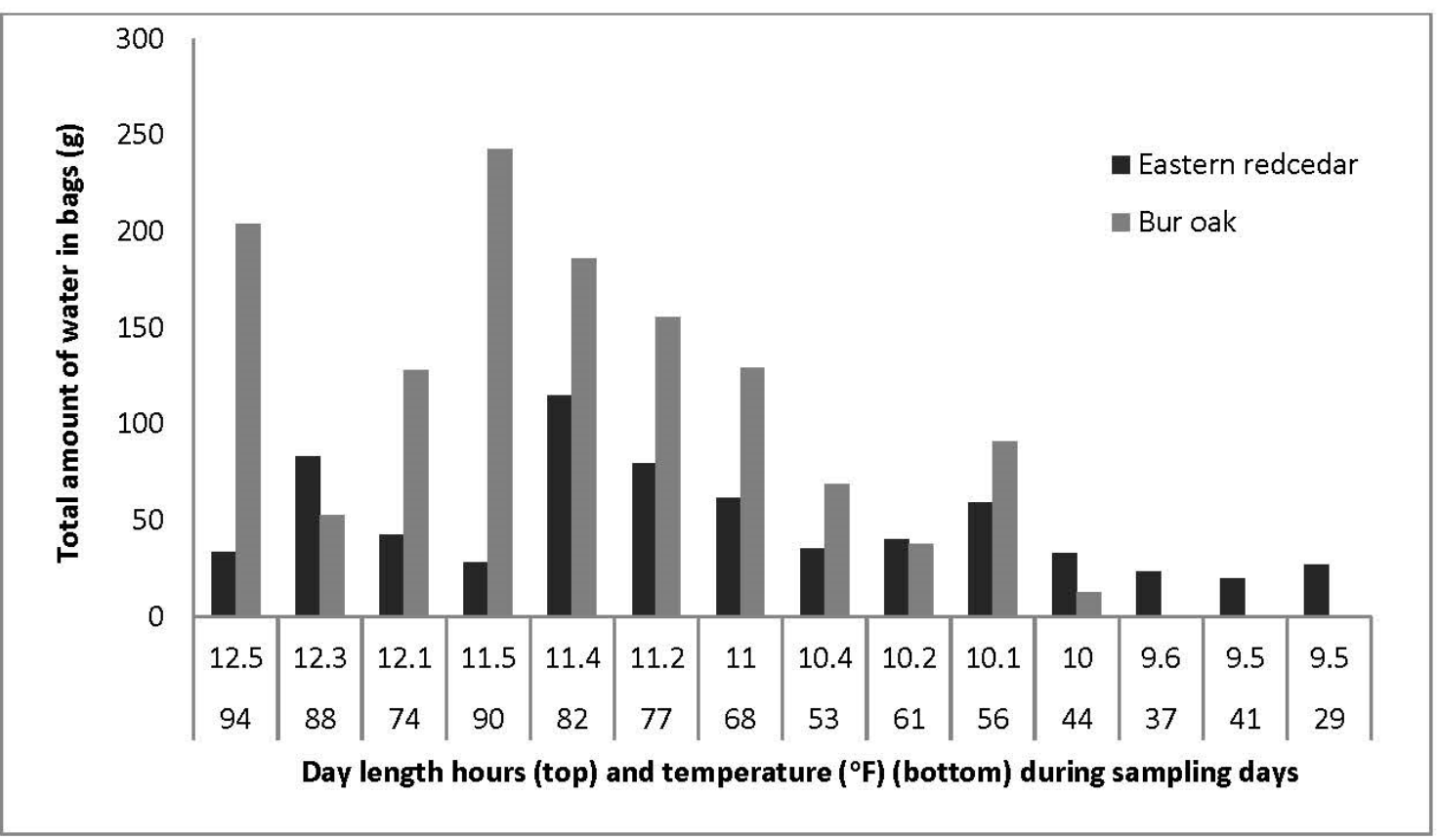

Figure 4 Combined effect of decreasing average daily temperature and decreasing day length hours on transpiration observed in the comparison study between eastern redcedar and bur oak during fall in rural northwestern Pottawatomie County 


\section{DISCUSSION}

Results of the study indicated that eastern redcedar transpired throughout the entire study period and more than observed in adjacent trees including loblolly pine (see Table 3). This may be partly due to the presence of stomata on both surfaces of the numerous scales (reduced leaves) of eastern redcedar. Although stomatal counts were not conducted in this study, leaf anatomical studies of a related species, western juniper (Juniperus occidentalis Hook), revealed stomatal distribution on both abaxial and adaxial surfaces of the scales with the majority of stomata occurring on the adaxial surface and near the margins (Miller and Shultz 1987). Unlike deciduous trees, transpiration in eastern redcedar did not greatly increase during the warm growing seasons but remained low to moderate even when seasons changed (see Figures 1 and 3). A study by Eggemeyer et al. (2009) on depth of water uptake in eastern redcedar growing in Nebraska using stable isotopes of hydrogen and oxygen revealed that in the winter, water uptake occurs from deeper levels of the soil below $0.9 \mathrm{~m}$ due to unfavorable low and extreme temperatures in upper soil profiles. However, in the warm seasons, water uptake in eastern redcedar occurred at the shallow soil levels between $0.05-0.5 \mathrm{~m}$. Uptake of water from the upper soil profiles during the warm seasons was associated with an increase in fine shallow roots (Eggemeyer et al. 2009). It has also been reported by Lawson (1990) that adults and seedlings of eastern redcedar are known for their fibrous and extensive root system that spreads widely in shallow and rocky soils. Furthermore, eastern redcedar is known to develop some form of deep penetrating taproot when growing in good soils, thereby enhancing water uptake from deeper levels and transpiration (Hung 2012). The ability for eastern redcedar to utilize soil water at variable depths in response to seasonal temperatures may account for the low to moderate amounts of transpiration of eastern redcedar observed in all the comparison investigations in the current study. Awada et al. (2013) also observed significant seasonal variability in transpiration in eastern redcedar with minimal transpiration observed in the winter from December to February when ambient temperatures fell below $0^{\circ} \mathrm{C}$. Similarly, in the present investigations, very low average amounts of transpiration were sampled for eastern redcedar during the cold months of February (see Figures 1a-c), November, and December (see Figures 3 and 4). However, the highest average amounts of water sampled from eastern redcedar were in April at the beginning of spring (see Figures $1 \mathrm{a}-\mathrm{c}$ ) and September at the end of summer (see Figure 3).

Average amounts of transpiration were also highest for loblolly pine, white mulberry, and cottonwood in April (see Figures $1 \mathrm{a}$ and c). Low transpiration was observed for loblolly pine in February compared to eastern redcedar. In general, average transpiration was observed to increase in March (see Figures 1a-c) when trees were leafing out. The results further show that eastern redcedar and loblolly pine (both conifers and evergreen) transpired in February when the deciduous trees were either dormant or lacked matured leaves. The trace amounts of water sampled for eastern cottonwood and white mulberry in February may have been due to condensation after a spike in ambient temperature on one sampling day (see Figures $1 \mathrm{~b}$ and 1c). Hydrogen isotopes used to determine water uptake from different soil levels in loblolly pine in North Carolina revealed that similar to eastern redcedar, water uptake during spring through fall occurred primarily in the upper soil profiles; whereas, in winter, water uptake occurred at lower soil profiles (Retzlaff et al. 2001). Our data suggest that eastern redecedar and loblolly pine may have similar water uptake

Adjoa R. Ahedor, et al. 
strategies (Eggemeyer et al. 2009; Retzlaff et al. 2001), as evident in the consistent amounts of water collected in the bags throughout the sampling period (see Figure 1a). The effect of humidity on transpiration in loblolly pine (see Table 4) supports its predominant southern distribution in the USA where average humidity may be higher than that on the grassland due to the forest ecosystem, coastal climate, and higher annual precipitation.

Awada et al. (2013) reported that in the winter, daily average air temperature was a major factor limiting transpiration in eastern redecedar followed by precipitation and photosynthetic active radiation. In that study, a slight increase in transpiration in eastern redcedar was measured in the months of March and April when environmental conditions improved as photosynthetic active radiation, temperature, and precipitation increased. Awada et al. (2013) further observed significant regression estimates between transpiration in eastern redcedar and daily air temperature when temperatures were above $0^{\circ} \mathrm{C}\left(32^{\circ} \mathrm{F}\right)$. Despite the limited sampling events of our current spring investigations, temperature was found to have a significant effect on transpiration in eastern redcedar (see Table 4). Similarly, day length had an effect on transpiration in eastern redcedar in the spring (see Figure 2 and Table 4). Therefore, it can be inferred from the results obtained that as day length increased from February to June, associated with an increase in temperature, transpiration increased in all trees, especially in eastern redcedar (see Figure 1). In late August through late September when day length was long (11.0-12.5 hours), transpiration was much higher in bur oak than in the adjacent eastern redcedar. However, as day length decreased (from October), transpiration drastically decreased in bur oak, and by late November and early December, negligible amounts were recorded. Eastern redcedar, on the other hand, maintained a consistent moderate to low transpiration even when day length decreased to 9.5 hours in early December. Despite the uneven sampling events for both spring and fall studies, the t-test paired samples results suggested that overall, day length and temperature are two weather variables that affected transpiration in eastern redcedar (see Table 4). Thus, further research will be necessary to better understand the combined effects of weather variables on transpiration in eastern redcedar.

In conclusion, the success of eastern redcedar in the semi-arid grassland may be due to multiple factors, including droughttolerance (Hung 2012), long growing season (Awada et al. 2013), water uptake strategies (Eggemeyer et al. 2009), and the effect of day length and temperature on transpiration, as observed in this study. Considering the mild and short winters, coupled with early spring typical of Oklahoma weather, transpiration in eastern redcedar appears to span all seasons. Transpiration is moderate during warm seasons but low during hot or cold seasons. Thus, overall, annual transpiration in eastern redcedar may be higher than in adjacent trees due to the consistent low to moderate transpiration all year round, regardless of season.

\section{ACKNOWLEDGMENTS}

The authors would like to thank Rose State College for partly supporting the project. Special thanks go to Wayne Jones, Jennifer Khoh, and Jo Hartman at the Engineering and Science Division for their assistance in securing supplies to conduct the research. Special thanks to the Editorial Board of ONPR; to Abigail Moore, Chuang Shao, and Leanne May; and to anonymous reviewers for providing comments on the paper. 


\section{LITERATURE CITED}

Awada, T., R. El-Hage, M. Gehe, D.A. Wedin, J.A. Huddle, X. Zhou, J. Msanne, R.A. Sudmeyer, D.L. Martin, and L.J. Brandle. 2013. Intra-annual variability and environmental controls over transpiration in a 58-year-old evenaged stand of invasive Juniperus virginiana L. in the Nebraska sandhills, USA. Ecobydrology 6:731-740.

Bernardo, D.J. 1986. An inventory of Oklahoma's range and pasture resources. Oklahoma Agricultural Experiment Station. Current Farm Economics 59:19-28.

Bihmidine, S., N.M. Byran, K.R. Payne, M.R. Parde, J.A. Okalebo, S.E. Cooperstein, and T. Awada. 2010. Photosynthetic performance of invasive Pinus ponderosa and Juniperus virginiana seedlings under gradual soil water depletion. Plant Biology 12:668-675.

Bragg, T.B. and L.C. Hulbert. 1976. Woody plant invasion of unburned bluestem prairie. Journal of Range Management 29:19-23.

Briggs, J.M., G.A. Hoch, and L.C. Johnson. 2002. Assessing the rate, mechanisms and consequences of the conversion of tallgrass prairie to Juniperus virginiana forest. Ecosystems 5:578-586.

Eggemeyer, K.D., T. Awada, F.E. Harvey, D.A. Wedin, X. Zhou, and C.W. Zanner. 2009. Seasonal changes in depth of water uptake for encroaching trees Juniperus virginiana and Pinus ponderosa and two dominant C4 grasses in a semiarid grassland. Tree Physiology 29:157-169.

Ghasemi, A. and S. Zahediasi. 2012. Normality tests for statistical analysis: A guide for non-statisticians. International Journal of Endocrinol Metabolism 10(2):486488.

Horncastle, V.J., E.C. Hellgren, P.M. Mayer, D.M. Engle, and D.M. Leslie. 2004. Differential consumption of eastern red cedar (Juniperus virginiana) by avian and mammalian guilds: Implications for tree invasion. The American Midland Naturalist 152:255-267.

Hung, C.J. 2012. Ecological effects of eastern redcedar encroachment in tallgrass prairie [Master's thesis]. Stillwater (OK): Oklahoma State University.

Huxman, T.E., B.P. Wilcox, D.D. Breshears, R.I. Scott, K.A. Synder, E.E. Small, K. Hultine, W.T. Pockman, and R.B. Jackson. 2005. Ecohydrological implications of woody plant encroachment. Ecology 86:308-319.

Jadrich, J. and C. Bruxvoort. 2011. Learning and Teaching Scientific Inquiry: Research and Applications. Arlington (VA): National Science Teachers Association Press.

Kramer, P.J. 1937. The relation between rate of transpiration and rate of absorption of water in plants. American Journal of Botany 24(1):10-15.

Lawson, E.R. 1990. Eastern redcedar. In: Burns, R.M. and B.H. Honkala, tech. coords. Silvics of North America: 1. Conifers; 2. Hardwoods. Agriculture Handbook. Washington (DC): U.S. Department of Agriculture. p 240-259.

McKinley, C.R. 2012. The Oklahoma redcedar resource and its potential biomass energy. Circular NREM-5054. Stillwater (OK): Oklahoma State University Cooperative Extension Service.

Miller, R.F. and L.M. Shultz. 1987. Water relations and leaf morphology of Juniperus occidentalis in the Northern Great Basin. Forest Science 33(3):690-706.

Oklahoma Climatological Survey. 2017. Oklahoma Mesonet Weather. http://www.mesonet.org (15 July 2017).

Retzlaff, W.A., G.K. Blaisdell, and M.A. Topa. 2001. Seasonal changes in water source of four families of loblolly pine (Pinus taeda L.). Trees - Structure and Function 15(3):154-162. 
Robinson, T.W. and D. Donaldson. 1967. Pontacyl brilliant pink as a tracer dye in the movement of water in phreatophytes. Water Resource Research 3(1):203-211.

Smith, S. 2011. Eastern Red-cedar: Positives, Negatives and Management. Circular. Ardmore (OK): The Samuel Roberts Noble Foundation.

Snook, E.C. 1985. Distribution of eastern redcedar on Oklahoma Rangelands. In: Wittwer, R.F. and D.M. Engle, eds. Conference Proceedings on Eastern Redcedar. Circular E-349. Stillwater (OK): Oklahoma State University Cooperative Extension Service. p 45-52.

SPSS, Inc. 2009. PASW Statistics for Windows, Version 18.0. Chicago (IL): IBM Corp.
Van Auken, O.W. 2009. Causes and consequences of woody plant encroachment into western North American grasslands. Journal of Environmental Management 90:2931-2942.

van Els, P., R.E. Will, M.W. Palmer, and K.R. Hickman. 2010. Changes in forest understory associated with Juniperus encroachment in Oklahoma, USA. Applied Vegetation Science 13:356-368.

Van Haverbeke, D.F. and R.A. Read. 1976. Genetics of eastern redcedar. Research Paper WO-32. Washington (DC): USDA Forest Service. 17 p.

Zar, J.H. 1996. Biostatistical Analysis. $3^{\text {rd }}$ Edition. Upper Saddle River (NJ): Prentice Hall 